\title{
The Effect of Coronavirus Disease 2019 (Covid-19) Towards Consumer Social Well-Being in Malaysia
}

\section{Zahrul Akmal Damin ${ }^{1 *}$, Khairunesa Isa ${ }^{1}$, Nor Shela Saleh ${ }^{1}$, Muhaymin Hakim Abdullah', Najah Ramlan²}

${ }^{1}$ Social Impact Focus Group, Centre for General Studies and Co-Curricular, Universiti Tun Hussein Onn Malaysia, 86400 Parit Raja, Batu Pahat, Johor, MALAYSIA

${ }^{2}$ Centre for Language Studies,

Universiti Tun Hussein Onn Malaysia, 86400 Parit Raja, Batu Pahat, Johor, MALAYSIA

*Corresponding Author

DOI: https://doi.org/10.30880/jstard.2020.02.03.017

Received 30 September 2020; Accepted 30 November 2020; Available online 31 December 2020

\begin{abstract}
Responding to the unprecedented threat of Covid-19 to the life of all humanity, it were directly affect human mentally and physicaly. This outbreak consequences lead to human well-being being affected. To break this infection chain, the government has been announced to implement the Movement Control Order (MCO). This study try to identify the consumer social well-being during MCO and the impact of social well-being based on household income. A total of 340 consumers around Malaysia were randomly selected to participate in this survey. This survey used Flanagan Quality of Life Scale (1970) indicator to measure the consumer's social well-being. The findings showed that the implementation of MCO made the aspect of consumers' social well-being still in good condition because most respondents rated five (5) out of fifteen (15) items as mostly satisfied (scale 5) to their quality of time during the implementation of MCO. Meanwhile, household income did not affect the level of their social well-being because most of the respondents concerned more on human relationship rather than financial. Overall it can be said that human touch and the element of interaction between human have a significant impact to human social well-being.
\end{abstract}

Keywords: Humanity, human touch, movement control order, social well-being

\section{Introduction}

The current situation faced by the nation and the world due to the outbreak of the COVID-19 pandemic has forced the Malaysian government to implement the Movement Control Order (MCO) to control and curb cases from increasing further. The implementation of MCO impacts the economic prosperity of individuals and family. The situation worsens as the scarce source of income, limited and lack of emergency savings are making life more difficult (Fazli Sabri, 2020). Therefore, consumers need to be more frugal in their expenses and only purchase essential items rather than meeting their wants. This study examines the level of consumer social welfare index during the period of the MCO and household income welfare index for the M40 and B40 groups. 


\section{Literature Review}

According to the Ministry of Health (MOH, 2020), COVID-19 pandemic is a dangerous disease that can severely affect the respiratory system. The disease was detected in mid-December 2019 in Wuhan City, Hubei China and was identified as a pandemic by the World Health Organisation (WHO) on March 11, 2020 (Warwick \& Roshen, 2020). Religious and sporting activities have led to the emergence of a culture of panic among society at the influence of the world economy (Aguiar et al., 2019; Ahmad et al., 2019). Epidemiological studies clearly show that COVID-19 pandemic attacks are prevalent in patients with primary diseases such as high blood pressure and diabetes. As of April 2020, the COVID-19 pandemic is still consistent in recording deaths in Malaysia (MOH, 2020).

The key of an implication is a very comprehensive and extremist global attack. According to Wasiul et al. (2020), COVID-19 has shocked the entire world when it is categorised as an aggressive pandemic, which occurrences have exploded all over the world. COVID-19 has also narrowed down numerous international issues and phenomena, particularly economic, social and political impacts (Warwick \& Roshen, 2020; Wasiul et al., 2020). Vicissitudes in the patterns and statistics of the world economy have affected global income including Malaysia. The epilogue to economic change began when the macroeconomic and micro-economic structure environment was affected by the outbreak. These changes require investors to change their investment smartness to ensure that the profitability of the investor remains stable (Barro, 2015; Kongoley, 2015).

The question is, how exactly does COVID-19 affect the quality of life of the people economically, socially and politically? The pandemic is very elusive, but the result is so great as it is wide-ranging and evolving drastically. Dramatic implications of this pandemic have been in effect since December 2019 and continue to war the world until 2020. In a report by Astro Awani (2020), a lecturer in the Department of Economics at Universiti Putra Malaysia (UPM) emphasised the high economic impact on three aspects in Malaysia, namely declines in export demand, domestic problems and the implications of implementing the Movement Control Order (MCO).

According to Saadiah (2020), the pressure on prices and lower inflation position a tangible challenge to the Malaysian economy, especially when foreign exchange rates are in question. However, the economic impact of the COVID-19 has a probable disadvantage similar to the Asian Financial Crisis in 1997/1998 (Mahanum, 2020). In this regard, to facilitate the economic movement, the Prime Minister of Malaysia proposes a People's Economic Stimulus Package (PRIHATIN) initiative to ensure that it provides a comprehensive and empowering economic stimulus to the people (Saadiah, 2020). PRIHATIN is one of the positive measures that will ensure people continue their trading activities in the country to maintain the buying and selling cycle in the Malaysian economic market.

Even though various steps and actions have been taken to alleviate this problem, the COVID-19 pandemic cannot be mitigated if Malaysians still practice a culture of travelling domestically and abroad when the outbreak is critical. Tourism is a great way to ensure a healthy balance of income, but tourism needs to be reduced for the outbreak to be fully defeated. In a study by Wasiul et al. (2020), he found that the COVID-19 pandemic greatly paralysed highlycorrelated economic activity with the tourism industry. These include the small industry of entrepreneurs in the sale of Malaysian-made product, the food industry, hospitality and even airlines. As a result, many national sources of income are affected, and this will contribute to the long-term economic downturn. This phenomenon is not only occurring in Malaysia, as it is also affecting the global economic crisis (OECD, 2020; Haque, Azam \& Chowdhury, 2019; Medina, 2020).

The economic crisis might be prevented if the people are seriously taking steps in reducing the pandemic in the country. According to Luqman Arif (2020), COVID-19 virus will continue to spread throughout the country if the people refuse to comply and are not disciplined. Furthermore, former Director-General of Health, Tan Sri Dr Ismail Merican found that quarantine phase, also known as mitigation, is a step that could have both positive and negative effects. However, the main problem during quarantine in Malaysia is the negative attitude and stubbornness in obeying the instructions issued. In South Korea, for example, its people are so well-disciplined that the government succeeded in reducing the spread of the virus without implementing strict rules (Astro Awani, 2020).

The strict rules are essential to ensure the well-being and safety. For example, the second wave infection in Malaysia began with the existence of multiple clusters which began in March 2020 (Luqman Ariff, 2020). Disobedience to hygiene practices can also be a factor of infection. An unhealthy lifestyle and a lack of self-awareness make a person feel 'healthier' even when they are infected. The Malaysian Ministry of Health is very concerned that no precaution is taken by the public. The possible impact is that the COVID-19 positive patient population will be of large scale, resulting in systematic treatment failure. Besides, Malaysia has only a few ventilator machines required for intensive care and respiratory assistance by many COVID-19 patients.

Precautions should be taken, particularly for those at high risk. According to MOH (2020), most COVID-19 patients are those with a history of chronic diseases including diabetes, high blood pressure, kidney failure and heart disease with a statistically significant rate of 80.7 percent. Disturbingly, the elderly and children are at high risk for this outbreak. Age statistics also showed that older people between the ages of 59 and over are at high risk (Rafidah, 2020). Additionally, the number of deaths in Malaysia, as of mid-April 2020, showed that COVID-19 male positive victims are more likely to die than female (MOH, 2020). However, there are currently no studies examining the major causes of gender differences in the context of COVID-19 patients in Malaysia. 
Due to the holistic effects of COVID-19 people should always be optimistic and positive throughout this period. Mental health needs to be taken care of (MOH, 2020). According to the BERNAMA (2020) report, some individuals suffered from mental disorders as a result of extreme emotional stress. For example, a survey showed that 46.6 percent (168, out of 182 respondents) lost their jobs because of the virus. Some suffered from lack of income. In terms of personal savings, only 71.4 per cent of respondents had savings of one to three months (Suzalina, 2020). This phenomenon has made it extremely difficult to continue survival during and after the outbreak. Besides, emotional tension can occur when individuals are too paranoid and scared in which can influence their psychology and physiology. According to the Secretary of the Malaysian Psychiatric Association (MPA), extreme fear can have longterm mental health effects. More ominously, one can also tend to commit suicide if emotions are not well-managed (Astro Awani, 2020). Generally, COVID-19 pandemic is a big issue and a problem that must be stopped. Systematic and continuous control requires the cooperation and support of all parties, especially both leaders and the people.

\section{Methodology}

A quantitative research approach was adopted to answer the objectives of the study via survey design. This design is a non-experimental method of research and is commonly applied in the field of social science. A survey was adopted because this design was able to obtain data directly and concurrently from the respondents of the study. The survey via Google Form was distributed to identify: (i) the consumer social well-being during MCO, and (ii) the impact of social well-being based on household income. The target sample was an individual consumer aged 15 years old and above. A total of 340 consumers around Malaysia were randomly selected to participate in this survey. This survey used Flanagan Quality of Life Scale (1970) indicator to measure the consumer's social well-being. The questionnaire consisted of four sections to answer all the research objectives (refer to Table 1). There were five components in Flanagan Quality of Life Scale (1970), namely (i) material and physical well-being, (ii) relationship with other people, (iii) social, community and civic activities, (iv) personal development and fulfilment, and (v) recreation (refer to Table 2).

Table 1 - The questionnaire section

\begin{tabular}{ccll}
\hline No. & Section & & Objective \\
\hline 1 & A & Respondent Demography & Scale \\
2 & B & To identify the consumer social well-being during MCO & Likert Scale \\
3 & C & To identify the impact of social well-being based on household income & \\
4 & D & To identify the consumer social well-being during MCO & \\
\hline
\end{tabular}

Table 2 - Flanagan quality of life scale and Malaysian Well-being Index (MyWi) items

\begin{tabular}{cl}
\hline No. & \multicolumn{1}{c}{ Flanagan Quality of Life Scale (1970) } \\
\hline 1 & Material and physical well-being \\
2 & Relationship with other people \\
3 & Social, community and civic activities \\
4 & Personal development and fulfilment \\
5 & Recreation \\
\hline
\end{tabular}

The original work by Flanagan used two 5-points scales of "importance" and "needs met." No reliability score of this scaling was reported at the time. Earlier work by Andrews and Crandall had suggested that a 7-points scale anchored with the words "delighted" and "terrible" was more sensitive and less negatively skewed than 5-points satisfaction scale for quality of life assessment, probably because it allowed for a broader range of affective responses to QOL items. The seven responses were "delighted" (7), "pleased" (6), "mostly satisfied" (5), "mixed" (4), "mostly dissatisfied" (3), "unhappy" (2), and "terrible" (1) as illustrated in Table 3. Therefore this study used this scale for Malaysian consumers during the MCO. The 7-points scale was used to measure satisfaction for the items, as shown in Table 1. All the items were analysed descriptively using SPSS version 24.

Table 3 - 7-Points scale

\begin{tabular}{ccccccc}
\hline $\mathbf{7}$ & $\mathbf{6}$ & $\mathbf{5}$ & $\mathbf{4}$ & $\mathbf{3}$ & $\mathbf{2}$ & $\mathbf{1}$ \\
\hline Delighted & Pleased & $\begin{array}{c}\text { Mostly } \\
\text { satisfied }\end{array}$ & Mixed & $\begin{array}{c}\text { Mostly } \\
\text { dissatisfied }\end{array}$ & Unhappy & Terrible \\
\hline
\end{tabular}




\section{Findings and Discussion}

\section{Section A: Respondent Demography}

A total of 340 respondents were involved in this study, with 38.5 per cent $(f=131)$ of them were males, and 61.5 per cent $(f=209)$ were females. More than half of the respondents 67.9 per cent; $(f=231)$ consisted of those aged between 15 to 24 years old, while 22.9 per cent $(f=78)$ were 25 to 34 years old, and 5.6 per cent $(f=19)$ aged between 35 and 44 years old. These findings showed that the dominant consumers who were actively spending in Malaysia were between the ages of 15 to 44 years as there were only a small number of consumers of 45 years old and above. From the total, the majority of the respondents were Malay ( 81.2 per cent; $f=297)$, followed by other ethnics $(9.1$ per cent; $f$ $=31)$, Chinese $(7.9$ per cent; $f=27)$, and Indian $(1.8$ per cent; $f=6)$. The respondents' demography is described in Table 3.

The analysis showed that a total of 82.1 per cent of consumers were singles $(f=297)$, followed by 17.1 per cent of them were married, and only 0.9 per cent was a widower. These findings showed that the respondents had a responsibility to the family because they were still aware of the family requirement even if they did not have much income. Moreover, the analysis showed that more than half (65.9 per cent) of the respondents were in B40 category (household with income less than RM 4000), and only 34.1 per cent of them were in M40 category (household with income between RM 4100 to RM 9619).

Out of the total respondents in this study, 63.8 per cent $(\mathrm{f}=217)$ had a total household of five, 43.5 per cent $(\mathrm{f}=$ 148 ) lived in the terraced-type residence, and 56.2 per cent $(f=191)$ resided in houses with 1 to 3 rooms. The findings showed that many respondents were required to share their room with more than one or two other siblings. Its corresponding findings showed that there could be psychological implications on respondents from sharing rooms due to the implementation of MCO. Meanwhile, 36.2 per cent $(\mathrm{f}=87)$ of the respondents had a total household of fewer than five people, some of them settled at the village or traditional house (13.2 per cent), apartment ( 9.4 per cent), semiD (8.5 per cent), bungalow (7.9 per cent), and flat (5.3 per cent). From the total, only 7.6 per cent of the respondents had more than five rooms. Nevertheless, most respondents or 73.5 per cent $(f=250)$ of them had their residence as compared to only 26.5 per cent of them were staying in rental houses.

Table 3 - Respondents' demographic information

\begin{tabular}{|c|c|c|}
\hline & Frequency $(\mathrm{F})$ & $\begin{array}{l}\text { Percentage } \\
(\mathbf{1 0 0 \% )}\end{array}$ \\
\hline \multicolumn{3}{|l|}{ Gender } \\
\hline Male & 131 & 38.5 \\
\hline Female & 209 & 61.5 \\
\hline Total & 340 & 100 \\
\hline \multicolumn{3}{|l|}{ Ethnic } \\
\hline Malay & 276 & 81.2 \\
\hline Chinese & 27 & 7.9 \\
\hline Indian & 6 & 1.8 \\
\hline Others & 31 & 9.1 \\
\hline Total & 304 & 100 \\
\hline \multicolumn{3}{|l|}{ Age } \\
\hline $15-24$ years & 231 & 67.9 \\
\hline $25-34$ years & 78 & 22.9 \\
\hline $35-44$ years & 19 & 5.6 \\
\hline $45-55$ years & 11 & 3.2 \\
\hline 60 years and above & 1 & 0.3 \\
\hline Total & 304 & 100 \\
\hline \multicolumn{3}{|l|}{ Income } \\
\hline B40 (RM < - RM4 000) & 224 & 65.9 \\
\hline M40 (RM 4100 - RM 9619 & 116 & 34.1 \\
\hline Total & 340 & 100 \\
\hline \multicolumn{3}{|l|}{ Number of Family Members } \\
\hline Less than 5 person & 123 & 36.2 \\
\hline 5 person and more & 217 & 63.8 \\
\hline Total & 340 & 100 \\
\hline \multicolumn{3}{|l|}{ Types of Residence } \\
\hline Condominium & 1 & 0.3 \\
\hline Apartment & 32 & 9.4 \\
\hline Flat & 18 & 5.3 \\
\hline
\end{tabular}




\begin{tabular}{lll} 
Traditional (village) & 45 & 13.2 \\
Terrace & 148 & 43.5 \\
Bungalow & 27 & 7.9 \\
Semi-D & 29 & 8.5 \\
Others & 40 & 11.8 \\
\hline Total & $\mathbf{3 4 0}$ & $\mathbf{1 0 0 . 0}$ \\
\hline Number of Rooms & & \\
1 - 3 rooms & 191 & 56.2 \\
4 - 5 rooms & 123 & 36.2 \\
More than 5 rooms & 26 & 7.6 \\
\hline Total & $\mathbf{3 0 4}$ & $\mathbf{1 0 0 . 0}$ \\
\hline Ownership & & \\
Rent & 90 & 26.5 \\
Owned & 250 & 73.5 \\
\hline Total & $\mathbf{2 8 0}$ & $\mathbf{1 0 0 . 0}$ \\
\hline
\end{tabular}

\section{Section B: Respondent Social Well-being during Movement Control Order (MCO)}

All respondents rated the importance of the 16 items on the original Flanagan QOLS. Table 4 summarises the findings by gender on the level of respondents' social well-being during Movement Control Order (MCO) due to COVID-19 pandemic. Based on the 7-points scale used, the level of respondents' social well-being was divided into three conditions; high (scale $7=$ delighted, $6=$ pleased, and $5=$ mostly satisfied), neutral (scale 4 ), and low (scale $3=$ mostly dissatisfied, 2 = unhappy, and $1=$ terrible).

The analysis showed that most respondents rated five (5) out of fifteen (15) items as mostly satisfied (scale 5) to their quality of time during the implementation of MCO, namely (i) material comforts home, food, conveniences, financial security, (ii) participating in organisations and public affairs, (iii) learning - attending school, improving understanding, getting additional knowledge, (iv) socialising - meeting other people, doing things, parties, etc, and (v) participating in active recreation. While the findings showed eleven (11) out of sixteen (16) items recorded score at scale 6, namely (i) health - being physically fit and vigorous, (ii) relationships with parents, siblings and other relatives - communicating, visiting, helping, (iii) having and raising the children, (iv) close relationships with a spouse or significant other, (v) close friend, (vi) helping and encouraging others, volunteering, giving advice, (vii) understanding yourself - knowing your assets and limitations - knowing what life is about, (viii) work - job or inhome, (ix) expressing yourself creatively, (x) reading, listening to music or observing entertainment, and (xi) independent, doing for yourself. According to Ali Shotar et al., (2015), infectious diseases affected the social element of human, especially on violent behaviour. However, the implementation of MCO made the aspect of consumers' social well-being still in good condition.

Table 4 - Level of respondent social well-being during Movement Control Order (MCO)

\begin{tabular}{|c|c|c|c|c|c|c|c|c|}
\hline No. & Item / Scale & 7 & 6 & 5 & 4 & 3 & 2 & 1 \\
\hline 1 & Material comforts home, food, conveniences, financial security & 59 & 118 & 128 & 12 & 15 & 8 & 0 \\
\hline 2 & Health - being physically fit and vigorous & 85 & 114 & 109 & 6 & 17 & 7 & 2 \\
\hline 3 & $\begin{array}{l}\text { Relationships with parents, siblings and other relatives - } \\
\text { communicating, visiting, helping }\end{array}$ & 94 & 124 & 94 & 13 & 7 & 6 & 2 \\
\hline 4 & Having and raising the children & 61 & 107 & 77 & 67 & 6 & 6 & 16 \\
\hline 5 & Close relationships with a spouse or significant other & 75 & 104 & 72 & 57 & 8 & 10 & 14 \\
\hline 6 & Close friend & 65 & 113 & 105 & 36 & 13 & 7 & 1 \\
\hline 7 & Helping and encouraging others, volunteering, giving advice & 51 & 111 & 105 & 47 & 16 & 9 & 1 \\
\hline 8 & Participating in organisations and public affairs & 28 & 69 & 87 & 83 & 35 & 25 & 13 \\
\hline 9 & $\begin{array}{l}\text { Learning - attending school, improving understanding, getting } \\
\text { additional knowledge }\end{array}$ & 35 & 75 & 84 & 60 & 38 & 19 & 29 \\
\hline 10 & $\begin{array}{l}\text { Understanding yourself - knowing your assets and limitations - } \\
\text { knowing what life is about }\end{array}$ & 65 & 116 & 110 & 38 & 7 & 3 & 1 \\
\hline 11 & Work - job or in-home & 65 & 97 & 87 & 42 & 25 & 12 & 12 \\
\hline 12 & Expressing yourself creatively & 59 & 119 & 107 & 39 & 5 & 7 & 4 \\
\hline 13 & Socialising - meeting other people, doing things, parties, etc & 32 & 72 & 75 & 65 & 34 & 24 & 38 \\
\hline 14 & Reading, listening to music or observing entertainment & 85 & 143 & 80 & 24 & 2 & 5 & 1 \\
\hline 15 & Participating in active recreation & 44 & 65 & 82 & 66 & 29 & 24 & 30 \\
\hline 16 & Independent, doing for yourself & 91 & 120 & 89 & 24 & 9 & 4 & 3 \\
\hline
\end{tabular}


According to Table 5, it can be concluded that there was no significant difference between man and woman on social well-being during the implementation of MCO. The findings found that the $\mathrm{t}$ value and significant value for each item were bigger than 0.05 (>0.05). Furthermore, the findings showed that the implementation of MCO was not significantly affecting the level of respondents' social well-being since most respondents rate 6 (Pleased) on items which were related to the relationship with others such as parents, siblings, relatives, spouse, children, close friends or volunteers.

Moreover, the findings showed that the respondents were satisfied with their social well-being, although according to the United States Public Health and National Securities Company, the infectious diseases could trigger direct or indirect threats to human and country (Ford, 2000). Meanwhile, Gostin and Hodge (2002) stated that the increase of world mortality rate due to the spreading of infectious diseases also affect the psychology and well-being of human especially for those with families involved. In the context of COVID-19 outbreaks in Malaysia, this study showed that consumers managed to reach their social well-being because they felt that their personal, health, community and food security were still protected.

Table 5 - The T-Test Rated between Man and Women in Social Well-being

\begin{tabular}{|c|c|c|c|c|c|c|}
\hline Item & Gender & $\mathbf{N}$ & Mean & Std. Deviation & $\mathbf{t}$ & Sig \\
\hline $\begin{array}{l}\text { Material comforts home, food, } \\
\text { conveniences, financial security }\end{array}$ & Man & 131 & 5.57 & 1.110 & .959 & .989 \\
\hline $\begin{array}{l}\text { Health - being physically fit and } \\
\text { vigorous }\end{array}$ & Woman & 209 & 5.45 & 1.100 & .957 & \\
\hline $\begin{array}{l}\text { Relationships with parents, siblings and } \\
\text { other relatives - communicating, }\end{array}$ & Man & 131 & 5.47 & 1.279 & -1.945 & .307 \\
\hline $\begin{array}{l}\text { visiting, helping } \\
\text { Having and raising the children }\end{array}$ & Woman & 209 & 5.73 & 1.137 & -1.894 & \\
\hline \multirow{2}{*}{$\begin{array}{l}\text { Close relationships with a spouse or } \\
\text { significant other } \\
\text { Close friend }\end{array}$} & Man & 131 & 5.75 & 1.119 & -.177 & .628 \\
\hline & Woman & 209 & 5.77 & 1.133 & -.178 & \\
\hline $\begin{array}{l}\text { Helping and encouraging others, } \\
\text { volunteering, giving advice }\end{array}$ & Man & 131 & 5.25 & 1.344 & .513 & .157 \\
\hline $\begin{array}{l}\text { Participating in organisations and public } \\
\text { affairs }\end{array}$ & Woman & 209 & 5.17 & 1.555 & .530 & \\
\hline $\begin{array}{l}\text { Learning - attending school, improving } \\
\text { understanding, getting additional } \\
\text { knowledge }\end{array}$ & Man & 131 & 5.31 & 1.503 & .249 & .714 \\
\hline $\begin{array}{l}\text { Understanding yourself - knowing your } \\
\text { assets and limitations - knowing what } \\
\text { life is about }\end{array}$ & Woman & 209 & 5.26 & 1.529 & .250 & \\
\hline Work - job or in-home & Man & 131 & 5.50 & 1.091 & .463 & .163 \\
\hline Expressing yourself creatively & Woman & 209 & 5.44 & 1.227 & .476 & \\
\hline $\begin{array}{l}\text { Socialising - meeting other people, } \\
\text { doing things, parties, etc }\end{array}$ & Man & 131 & 5.26 & 1.187 & -.525 & .907 \\
\hline $\begin{array}{l}\text { Reading, listening to music, or observing } \\
\text { entertainment. }\end{array}$ & Woman & 209 & 5.33 & 1.217 & -.528 & \\
\hline \multirow[t]{2}{*}{ Participating in active recreation } & Man & 131 & 4.63 & 1.515 & .868 & .976 \\
\hline & Woman & 209 & 4.49 & 1.497 & .866 & \\
\hline $\begin{array}{l}\text { Material comforts home, food, } \\
\text { conveniences, financial security }\end{array}$ & Man & 131 & 4.64 & 1.715 & 1.060 & .918 \\
\hline $\begin{array}{l}\text { Health - being physically fit and } \\
\text { vigorous }\end{array}$ & Woman & 209 & 4.44 & 1.695 & 1.057 & \\
\hline $\begin{array}{l}\text { Relationships with parents, siblings and } \\
\text { other relatives - communicating, }\end{array}$ & Man & 131 & 5.50 & 1.011 & -.389 & .291 \\
\hline $\begin{array}{l}\text { visiting, helping } \\
\text { Having and raising the children }\end{array}$ & Woman & 209 & 5.55 & 1.109 & -.397 & \\
\hline $\begin{array}{l}\text { Close relationships with a spouse or } \\
\text { significant other }\end{array}$ & Man & 131 & 5.05 & 1.597 & -.996 & .425 \\
\hline Close friend & Woman & 209 & 5.22 & 1.483 & -.979 & \\
\hline
\end{tabular}




\begin{tabular}{|c|c|c|c|c|c|c|}
\hline $\begin{array}{l}\text { Helping and encouraging others, } \\
\text { volunteering, giving advice }\end{array}$ & Man & 131 & 5.33 & 1.255 & -1.433 & .349 \\
\hline $\begin{array}{l}\text { Participating in organisations and public } \\
\text { affairs }\end{array}$ & Woman & 209 & 5.52 & 1.131 & -1.399 & \\
\hline $\begin{array}{l}\text { Learning - attending school, improving } \\
\text { understanding, getting additional } \\
\text { knowledge }\end{array}$ & Man & 131 & 4.47 & 1.866 & .945 & .236 \\
\hline $\begin{array}{l}\text { Understanding yourself - knowing your } \\
\text { assets and limitations - knowing what } \\
\text { life is about }\end{array}$ & Woman & 209 & 4.28 & 1.735 & 929 & \\
\hline Work - job or in-home & Man & 131 & 5.64 & 1.157 & -1.986 & .051 \\
\hline Expressing yourself creatively & Woman & 209 & 5.87 & .955 & -1.901 & \\
\hline $\begin{array}{l}\text { Socialising - meeting other people, } \\
\text { doing things, parties, etc }\end{array}$ & Man & 131 & 4.57 & 1.780 & .432 & .662 \\
\hline $\begin{array}{l}\text { Reading, listening to music, or observing } \\
\text { entertainment. }\end{array}$ & Woman & 209 & 4.49 & 1.738 & 430 & \\
\hline \multirow[t]{2}{*}{ Participating in active recreation } & Man & 131 & 5.53 & 1.291 & -2.002 & .100 \\
\hline & Woman & 209 & 5.79 & 1.079 & -1.922 & \\
\hline
\end{tabular}

\section{Section C: The Impact of Social Well-being Based on Household Income}

Table 6 describes the impact of respondents' social well-being according to two different categories of household income, namely M40 and B40. This study showed that the t value $=0.641$, and the significant level; $\mathrm{p}=0.523(\mathrm{p}>$ 0.05). There was no significant difference between these two groups on their social well-being. According to Fatan Hamamah (2005), the spreading of the infectious disease gave a big challenge to social and economic aspect since it affected economic implication in terms of direct and indirect cost (Fatan Hamamah \& Saadiah, 2000) to the patient, their families and government as well. The current situation of COVID-19 outbreak showed many Malaysians struggling to manage finances which impacted on the well-being of their own and family. With this pandemic, the Malaysian consumers faced many challenges, such as being terminated by the company, the income sources became limited, and the situation becoming worse when they had no emergency savings. Financial stability played a central role in human life, especially during a pandemic crisis such as COVID-19, but the findings demonstrated that household income did not affect the level of their social well-being. According to the respondents, the most valuable thing that could contribute to their social well-being was their relationship with others.

Table 6 - impact of social well-being based on household income

\begin{tabular}{|c|c|c|c|c|c|c|}
\hline Item & $\begin{array}{l}\text { Household Income } \\
\text { Category }\end{array}$ & $\mathbf{N}$ & Mean & Std. Deviation & $\mathbf{t}$ & Sig \\
\hline Social Well-being & $\begin{array}{l}\text { B40 } \\
\text { M40 }\end{array}$ & $\begin{array}{l}224 \\
80\end{array}$ & $\begin{array}{l}5.22 \\
5.33\end{array}$ & $\begin{array}{l}1.110 \\
1.100\end{array}$ & $\begin{array}{l}.641 \\
.638\end{array}$ & $\begin{array}{l}.523 \\
.524\end{array}$ \\
\hline
\end{tabular}

\section{Conclusion}

In conclusion, the MCO period is a very convenient and practical time for all consumers to adopt a simple, economical and prudent lifestyle. This practice must be continued even after the world recovers from the spread of the COVID-19 pandemic outbreak in preparation for any disasters and other emergencies that may happen to oneself and family. The aid provided by the government is only temporary. Consumers need to be prepared and allocate cash emergency funds for themselves and their families for the intermediate and long term use. This method is a good strategy and can help reduce financial stress to ensure social well-being and household income. Additionally, the emergency fund will also act as a buffer against the financial burdens when faced with global economic collapse. It is hoped that consumers will be able to get through this physical, emotional, spiritual and economical challenges phase with patience, awareness and simplicity.

\section{Acknowledment}

The author would like to thank the Public Service Department (JPA) for its trust in providing financial sponsorship "Federal Training Prize (HLP)". The author also thanks the Department of Statistics Malaysia (DOSM) for the use of data in this paper. The author is responsible for the integrity of the data and the accuracy of the data analysis. The author also thanks the anonymous commenters and editors for providing helpful comments. 


\section{Reference}

[1] Aguiar, A., Chepeliev, M., Corong, E., McDougall, R., \& van der Mensbrugghe, D. (2019). The GTAP Data Base: Version 10. Journal of Global Economic Analysis, 4(1), 1-27

[2] Ahmad, A. H., Ibrahim, A., Ahmad, Z. H., \& Masri, R. (2019). The Predictors of Sports Tourism Involvement in Malaysia: An Extreme Sport Overview. Humanities \& Social Sciences Reviews, 7(2), 449-453

[3] Ali Shotar, Sukaina A, Alzyoud \& Ahed J. AlKhatib. (2015). Social Impact of Infectious assn. org/cgi/content/ full/288/5/622

[4] Astro Awani (2020). COVID-19: Ketakutan kepada Penyakit Sebabkan Kesan Emosi yang Teruk. Astro Awani, 31 Mac 2020. Retrieved at http://www.astroawani.com/berita-malaysia/covid-19-ketakutan-kepadapenyakit-sebabkan-kesan-emosi-yang-teruk-236043 on 20 April 2020

[5] Astro Awani (2020). Fahami Cara COVID-19 Beri Impak kepada Rakyat dan Ekonomi. Astro Awani, 30 Mac 2020. Retrieved at http://www.astroawani.com/berita-malaysia/fahami-cara-covid-19-beri-impak-kepadarakyat-dan-ekonomi-235835 on 20 April 2020

[6] Astro Awani (2020). Impak COVID-19 Lebih Buruk daripada Krisis Kewangan Global-IMF. Astro Awani, 4 April 2020. Retrieved at http://www.astroawani.com/berita-dunia/impak-covid-19-lebih-buruk-daripadakrisis-kewangan-global-imf-236721 on 20 April 2020

[7] Barro, R. J. (2015). Convergence and Modernisation. Economic Journal, 125 (585), 911-942.

[8] BERNAMA (2020). COVID-19: Risiko Masalah Mental, Perlu Penyelesaian Terbaik -Pakar. BERNAMA, 17 April 2020. Retrieved at https://www.bernama.com/bm/news.php?id= 1827662 on 20 April 2020.

[9] Coordination and Humanitarian Affairs United Nations, hlm 6

[10] Disease: Latent Toxoplasmosis and Crime. The Social Sciences. 10 (7). 1677-1681. General Accounting Office Washington, hlm 2

[11] Fatan Hamamah Yahaya (2005). Kemunculan Penyakit Berjangkit dan Kesannya Terhadap Manusia di Malaysia. Laporan Penyelidikan. 23. 153-168

[12] Fatan Hamamah Yahaya \& Saadiah Mohamad. 2000. AIDS: Implikasi Kos dan Wanita Alaf Baru yang Asertif. Seminar Kebangsaan Wanita Malaysia dalam Alaf Baru, anjuran Southeast Asian Association for Gender Studies, Malaysia Branch (SAMA) \& Jabatan

[13] Sains Politik, Universiti Kebangsaan Malaysia, 16-17 September 2000, Shah's Village Hotel, Petaling Jaya, Selangor

[14] Ford, Brian J., 2000a, (ed) The First Fifty Years, 135 pp., ISBN 00900490373 (h/b), 0900490 $381(\mathrm{p} / \mathrm{b})$, London: Institute of Biology

[15] Gostin, K.G and Hodge, J. G. (2002). C Challenging Themes in American Health Information Privacy and the Public's Health: Historical and Modern Assessments. The Journal of (4). 670-679

[16] Haque, A., Azam, S. F., \& Chowdhury, N. A. (2019). Factors Affecting Purchase Behaviour of Shariah Compliant Hotels: A Study From Muslim Consumers' Perspective. International Journal of Islamic Marketing and Branding, 4(2), 104-123

[17] Health Power Act: Planning for and Response to Bioterrorism and Naturally Occurring http:// www.hdr.undp.org/en/media/HS_Handbook_2009.pdf

[18] Human Security in Theory and Practice, Application of the Human Security Concept and the United Nations Trust Fund for Human Security, Human Security Unit, Office for the Infectious Diseases” in. JAMA 288:5 (622-628), hlm 623, 2002. http://jama.ama-

[19] Jess T. Ford, 2000. "A Report on Global Health: Framework for Infectious Disease Surveillance, G.A.O” dlm. National Security and International Affairs Division, United States

[20] Kongoley-MIH, P. S. (2015). The Impact of Ebola on the Tourism and Hospitality Industry in Sierra Leone. International Journal of Scientific and Research Publications, 5(12), 542-550

[21] Lawrence O. Gostin, Jason W. Sapsin \& Stephen P. Teret et al., "The Model State Emergency

[22] Luqman Arif Abdul Karim (2020). COVID-19: Penularan Luar Kawalan Jika Rakyat Tiada Disiplin Diri. Berita Harian, 21 Mac 2020. Retrieved at https://www.bharian.com.my /berita/nasional/2020/03/667544/covid-19-penularan-luar-kawalan-jika-rakyat-tiada-disiplin-diri on 20 April 2020

[23] Mahanum Abdul Aziz (2020). Sistem Kewangan, Ekonomi Malaysia Mampu Depani Kesan COVID-19. Berita Harian, 3 April 2020. Retrieved at https://www.bharian.com.my/ bisnes/lainlain/2020/04/672432/sistem-kewangan-ekonomi-malaysia-mampu-depani-kesan-covid-19 on 20 April 2020.

[24] Medina, A. F. (2020, March 19). Malaysia Issues Stimulus Package to Combat COVID-19 Impact. Retrieved at https://www.aseanbriefing.com/news/malaysia-issues-stimulus-package-combat-covid-19-impact/ on 20 April 2020.

[25] MOH (2020). Portal Rasmi Kementerian Kesihatan Malaysia. Acessed at http://www.moh. gov.my on 17, 18, 20 dan 22 April 2020 
[26] Mohamad Fazli Sabri (2020). Kesedaran rakyat miliki dana kecemasan masih kurang. Berita Harian, 18 April 2020. Retrieved at https://www.bharian.com.my/rencana/muka10/2020/04/678486/kesedaran-rakyat-milikidana-kecemasan-masih-kurang?fbclid=IwAR $\quad$ 2uKXOYs_LnguDre_ i $\quad$ i3xZT64oPyPK4nBc29OBHEKluyaU813zRXgg-P0E on 27 April 2020

[27] OECD (2020). Retrived at http://www.oecd.org/newsroom/global-economy-faces-gravest-threat-since-thecrisis-as-coronavirus-spreads.htm on 20 April 2020

[28] Rafidah Mat Ruzki \& Luqman Arif Abdul Karim (2020). COVID-19: Dua Kelompok Usia Warga Emas Berisiko Tinggi. Berita Harian, $16 \quad$ April 2020. Retrieved at https://www.bharian.com.my/berita/nasional/2020/04/677978/covid-19-dua-kelompok-usia-warga-emasberisiko-tinggi on 20 April 2020

[29] Saadiah Ismail (2020). COVID-19: Inisiatif PRIHATIN Amat Menyeluruh, Berpaksikan Rakyat - FELDA. Berita Harian, 30 Mac 2020. Retrieved at https://www.bharian.com.my/ berita/nasional/2020/03/671164/covid-19-inisiatif-prihatin-amat-menyeluruh-berpaksikan-rakyat-felda on 20 April 2020

[30] Suzalina Halid (2020). COVID-19: Kira-kira 78, 372 Responden Hilang Pekerjaan. Berita Harian, 9 April 2020. Retrieved at https:/www.bharian.com.my/berita/nasional/ 2020/04/674919/covid-19-kira-kira-78372responden-hilang-pekerjaan on 20 April 2020

[31] Warwick McKibbin \& Roshen Fernando (2020). The Global Macroeconomis Impacts of COVID-19: Seven Scenarios. CAMA Working Paper 19/2020, 1-43

[32] Wasiul Karim, Ahasanul Haque, Zohurul Anis \& Mohammad Arijie Ulfy (2020). The Movement Control (MCO) for COVID-19 Crisis and its Impact on Tourism and Hospitality Sector in Malaysia. International Tourism and Hospitality Journal, 3(2), 1-7. https://www.permohonan.my/maksud-b40-m40-dant20/\#GOLONGAN_B40 